\title{
COMPARISON OF CUTTING TOOL INSERT'S MADE OF OXIDE CUTTING CERAMIC MACHINING OF GREY CAST IRON
}

\author{
Kovalčík Jaroslav \\ Department of Machining and Assembly, TU in Liberec
}

In this article there you can find comparisons of several types of cutting tool insert's of oxide cutting ceramics machining of grey cast iron. Experiments had to serve the realization of long-term durability tests. Very important angle for balance was the index of Taylor's equation that represents the influence of cutting speed on the durability and power optimization. By experimenting, there were discovered precious features of some kinds of compared cutting tool insert's and their references to the power optimization for machining grey cast iron.

Keywords: machining of metal, cutting ceramics, durability, tool wear

\section{References}

[1] Humár, A. Materiály pro řezné nástroje. 1. vyd. MM publishing, s. r. o. Praha, 2008. ISBN 978-80-254-2250-2.

[2] Sandvik Coromant. Př́ručka obrábění. 1. vyd. Praha 1997. ISBN 91-972299-4-6.

[3] HOLEČEK V. Zkoušky řezné keramiky-výkonová optimalizace. [Diplomová práce]. TU Liberec, 2002. Fakulta strojní. $69 \mathrm{~s}$.

[4] HRADEC, V. Zkoušky oxidické řezné keramiky se zirkonem. [Diplomová práce]. TU Liberec, 2002. Fakulta strojní. $64 \mathrm{~s}$.

[5] KOVALČíK, J. Analyticko-syntetická studie na souboru řezných destiček z keramiky. [Diplomová práce]. TU Liberec, 2008. Fakulta strojní. $104 \mathrm{~s}$.

[6] VOBORNÍK, L. Zkoušky oxidické a směsné rezné keramiky. [Diplomová práce]. TU Liberec, 2003. Fakulta strojní. $79 \mathrm{~s}$.

[7] DLOUHÝ, R. Srovnávací zkoušky řezivosti nitridové keramiky. [Diplomová práce]. TU Liberec, 2001. Fakulta strojní. $67 \mathrm{~s}$. 